Journal of Social Sciences 4 (3): 158-164, 2008

ISSN 1549-3652

(C) 2008 Science Publications

\title{
Rural-Urban Migration and Earning Gains in Iran
}

\author{
Mohammad Ali Molaei, A. Solucis Santhapparaj and C.A. Malarvizhi \\ Faculty of Management, Multimedia University, 63100 Cyberjaya, Malaysia
}

\begin{abstract}
This study analyzed the impact of earning gains of the rural migrants settled in urban areas in Iran. Primary data has been collected from 400 migrant households based on multistage cluster random sampling. A OLS regression equation has been estimated to study the factors determining the migrants' earning in the urban areas. The findings reveled that migrants' demographic characteristics, sector of employment and migrants' network had significant impact on the earning of the migrants.
\end{abstract}

Key word: Internal Migration, Earning Gain, Wage Difference, Iran

\section{INTRODUCTION}

Migration can be considered a significant feature of livelihoods in developing countries is pursuit of better living standards. Ever since the seminal work of Ravenstein $^{[1]}$ numerous studies have explored various aspects of this pervasive phenomenon. Issues covered by the literature include the rationale for migrating ${ }^{[2,3]}$, migration patterns ${ }^{[1,4]}$, and the welfare impacts of these population movements ${ }^{[5-7]}$. The enormous research interest in migration is a reflection of the prevalence of this livelihood activity ${ }^{[8]}$.

In recent years, the migration literature has given considerable coverage to international migration, due to the effects of this form of migration on remittances and labour supply. However, for many developing countries, internal migration is a very important feature of households' livelihoods. The literature on internal migration has, however, been dominated by studies that focus on rural to urban migration ${ }^{[3,8-10]}$. This emphasis on rural urban migration is attributable - at least partly to the rising levels of urbanization in these countries, in the context of rural- urban migration employment and higher income are two most dominant factors underlying migration. But adequate attention has not given to the earning and income condition after migration to the city. Are migrants really better off than they would have been in the absence of migration? Is the impact of migration on earnings favorable to all migrants? These questions form the main thrust of this study.

By and large, the literature's broad consensus is that migration results from forward-looking behaviour that aims to maximize an individual or household's expected well-being over some time horizon by means of relocation. It is in all cases a cost-benefit calculation, comparing a stream of expected future benefits with costs, both appropriately discounted to the present. On the whole, the issue of upward mobility ${ }^{[11]}$ and the inter-play of various factors that qualify a migrant to experience upward mobility is complex, and rich quantitative information is required to lend support to theoretical underpinnings ${ }^{[7]}$, hence an inquiry about one of the main causes of migration ( earning gains) play a considerable role to achieve better understanding of above issues.

In other word migration is often a response to economic incentives. The classic analysis of rural-urban migration $^{[12]}$ attributes migration to the existence of relatively better economic conditions in urban areas. According to this model, migrants compare expected wages in the city to alternative rural income. If urban wages are higher than rural ones, rural workers will be attracted to the city. If expected urban income is much higher than rural income, rural-urban migration may occur even if the employment prospects in the city are dim. Migrants may be willing to endure a period of unemployment if expected urban income is sufficiently $\operatorname{high}^{[13]}$.

Aside from the higher expected urban income pulling rural people into urban areas, the low income in rural area act as a push factor. A general decline in agricultural commodity prices may contribute to a decline in rural incomes, which can be highly vulnerable to world market price fluctuations. Increased population density and environmental degradation may also lead to land shortage among rural people, encouraging out-migration. Moreover, higher agricultural productivity in the rural areas releases people and resources for migration into the city. Rural-

Corresponding Author: A. Solucis Santhapparaj, Faculty of Management, Multimedia University, 63100 Cyberjaya, Malaysia Te 1: +60383125679 
Table1: Annual average income of rural and urban households in Iran during 1986-2004 (Rial)

\begin{tabular}{|c|c|c|c|c|}
\hline Year & $\begin{array}{l}\text { Urban } \\
\text { household's } \\
\text { income }\end{array}$ & $\begin{array}{l}\text { Rural } \\
\text { household's } \\
\text { income }\end{array}$ & $\begin{array}{l}\text { Income } \\
\text { differentials }\end{array}$ & $\begin{array}{l}\text { Ratio of rural } \\
\text { to urban } \\
\text { income }\end{array}$ \\
\hline 1986 & 1126639 & 568558 & 558081 & 50.46 \\
\hline 1991 & 284 & 25 & 127 & 55.02 \\
\hline 1996 & 9879358 & 5865027 & 4014331 & 59.36 \\
\hline 2004 & 47267784 & 27883656 & 19384128 & 59.00 \\
\hline 2006 & 53678282 & 34474686 & 19203593 & 64.22 \\
\hline
\end{tabular}

Source: Statistical centre of Iran, 2008

urban migration may also follow from a risk diversification strategy. Agricultural income can be highly variable due to changes in climate, agricultural market prices, access to land, and illness. Some rural household members may migrate to urban areas to reduce family vulnerability to these risks, especially if times of economic adversity in urban areas do not normally coincide with those of rural areas.

Majority of studies concur that migrants leave their area of origin primarily because of lack of economic opportunities in the hope of finding better opportunities elsewhere $^{[14-18]}$.

Most of the studies and surveys in Iran support this thinking that aspiration for higher income is a significant motivating factor for migration. According to Mohtadi's ${ }^{[19]}$ survey, the most important reason for rural-urban migration in Iran was higher wages in cities, especially in Tehran, and consequently, higher income for migrants. Table 1 shows that in Iran during 1986-2004, the annual average income of rural households was less than $60 \%$ of the annual average income of urban households, but it increased after 2004 and reached to more than $60 \%{ }^{[20]}$. Despite of the growth in rural income in recent years and decrease in income differentials, rural-urban migration and urbanization have been had their accretion.

According to Sheykhi's ${ }^{[21]}$ study, near to $39 \%$ of the migrants came to urban areas because of low level of income in their villages. Another study pointed out that the major pull factors in the migration occurring in 1976 in Iran were related to the increasing income of villagers from non-agricultural activities in urban centers $^{[19,22]}$.

The consequences of migration are no less significant than the causes of migration. The study of consequences of migration, which so far has received little attention especially in Iran, offers another vital area of research for the academics and policymakers in a number of countries. Rural-urban migration has a number of economic, social, cultural, mental and demographic impacts ${ }^{[23]}$. Relatively little has been published in the regional science literature regarding migration's impact on migrants and their households. The relative dearth of research on migration's consequences is troubling given its practical importance. Migration provides a primary means for individuals and places to adjust to social and economic changes. For many individuals, migration clearly improves welfare, yet it does not work out so well for others, including many who return home. It would help to know which personal and contextual characteristics associate with successful migration and which associate with unsuccessful migration.

So this study attempts to highlight some part of economic consequences of migration on migrants and their households by assessing their earning situation. Hence, this survey adopted a comparison of earnings of migrants before and after migration and its determinants to understand the economic impact of migration on migrants and their households.

\section{MATERIALS AND METHODS}

To achieve the mentioned aim of the study, a sequential steps procedure of collection of data, analyzing (processing and interpretation) the data and analytical tools are used. Besides tabular analysis based on means and averages, cross tabular and the log leaner regression methods were applied to analyze the determinants accountable for earnings of migrants in Iran.

Data: Iranian nationwide census report is a major source of secondary data on migration. But it does not provide the socio-economic characteristics of the migrant's households and their earnings. Consequently identifying of determinants and consequences of migration requires more information, which is feasible via primary data. Then it was necessary to generate such primary data directly by contacting the migrants.

Basically the sample unit of the present study is migrant who is a male and has migrated to urban area between 1995 and 2000 in form of voluntary migration, as well as their households. The migrant should have at least 5 years of urban experience as a resident of urban.

As it was felt to be not feasible to make an in-depth study of all the in-migrants the researcher chose a sample study. A total number of 400 sample migrant's households were interviewed. The actual process of selecting the migrant was carried out stage by stage by following the method of multistage cluster random sampling. 
Sampling design: There was no ready-made list of migrant households from secondary sources. So it was decided to go ahead first personally for identifying the migrant household and then selecting a few of them for interview at a later stage. Migrant households are to be found in almost all the parts of the cities. According to the census there were 25 provinces in Iran. Out of them three province were selected by simple random sampling.

In the next stage one district of each province were selected by simple random sampling and then by the same method one city and in each city three residential areas were selected. In order to give equal representation to all areas 50 samples were collected from each residential area, aimed to have at least to have a total of 400 samples households.

Collecting of data (Interview schedule): With the help of the pre-tested interview schedule, a field survey was conducted and the primary data were collected. The interviews were carried out with a semi-structured, open-ended questionnaire. The interviewees were asked to answer questions on why they came to the city and what was the most important factor to migrate with respect to ranking of other factors, how they found job, job-changing history, changes of earning and income, saving, investment, indebtedness over time, education and training, sources of financial support, family and extended family, and living conditions. In order to collect correct pre-migration particulars and present the details accurately, great care was taken and cross questions were put across to the respondents. So interview took around $30 \mathrm{~min}$ to complete.

The interviews were conducted from January to July of 2007 with help of three specifically for that survey trained interviewers. The interviewers were generally informed of the goal and approach of this study. Brief information on the goal of the study was given to the interviewees as well. Normally the information was collected from the head of the household, who had taken the decision to migrate, but in very few cases, due to non-availability of the head the man next in position in the household was interviewed.

The interviewees were found in the houses. Most of households agreed to do the interview, and interviewees were assured of confidentiality before the interviews started. There were 450 interviewees in total, and 50 interviews were excluded because of noncooperation, answers seriously and influenced by the presence of others.

\section{RESULTS AND DISCUSSIONS}

Earning changes: Table 2 shows the earnings of the migrants at the time of migration and the earnings at the time of survey in city, to clarify earning levels distribution of migrants before and after migration as well as changes in these levels.

Out of the 400 migrants, $53.6 \%$ of the migrants earned up to $1000000 \mathrm{R} l s$. per month before migration (including the students and unemployed at the time of migration). Majority of the migrants $(85.1 \%)$ earned only up to $2000000 \mathrm{R} 1 \mathrm{~s}$. Only $15.3 \%$ of the migrant earned more than 2000000Rls. per month and 4.3\% earned above 3000000Rls. per month before migration.

After migration, only $5 \%$ of the migrant earned below 500000Rls. per month and $24.5 \%$ earned up to $1000000 R$ ls. from their job in city. Nearly $78 \%$ were earning up to 2000000 Rls. per month, $12 \%$ earned above $2000000 \mathrm{R} 1 \mathrm{~s}$ up to $3000000 \mathrm{R} 1 \mathrm{~s}$. and $10 \%$ of the migrants earned above 3000000Rls. per month from their job in the city.

An assessment of the earning data before and after migration shows that considerable percentage of the migrants' (26. 7\%) earnings had moved from below 500000Rls. per month to higher income levels. Overall analysis indicates that there is considerably percentage of shift in their earnings to higher income group.

The average earning of the migrants at the time of migration was $1170878 \mathrm{R} l s$. per month and after excluding the migrants who were students and unemployed the average earning was 1466110Rls. month $^{-1}$ whereas after migration average earnings for migrants had increased to $1933257 \mathrm{Rls}$. (65.11\% income gain in the earnings compare to earnings before migration for all sample respondents).

Out of the 114 migrant in earning group of below 500000Rls. per month before migration, a few migrants (6.1\%) were in the same earning group level even after migration and majority $(93.9 \%)$ of them moved to the higher level of income. Largest percentage $(62.3 \%)$ of the migrants had moved to two next income groups which those gained income more than 500000Rls.2000000Rls.

Out of the 99 migrants in the earning group of 500000-1000000Rls. per month before migration, $41.4 \%$ of them were in the same earning group after migration and another 5.1 of the migrants were pushed to a lower income than before migration. And a considerable proportion $(35.4 \%)$ moved to the next earning group of 1000001-1500000Rls. The rest 11.1 and $7.1 \%$ moved to earning groups of $1500001-$ 2000000 Rls. and more then $3000000 \mathrm{R} 1 \mathrm{~s}$. respectively. 
J. Social Sci., 4 (3): 158-164, 2008

Table 2: Classified monthly earning at the time of migration * classified monthly earning at the time of survey cross tabulation

\begin{tabular}{|c|c|c|c|c|c|c|c|c|}
\hline \multirow{2}{*}{$\begin{array}{l}\text { Classified } \\
\text { earning at } \\
\text { the time of } \\
\text { migration }\end{array}$} & \multicolumn{7}{|c|}{ Classified earning at the time of survey } & \multirow[b]{2}{*}{ Total } \\
\hline & $\begin{array}{l}\text { Below } \\
500000\end{array}$ & $\begin{array}{l}500000- \\
1000000\end{array}$ & $\begin{array}{l}1000001- \\
1500000\end{array}$ & $\begin{array}{l}1500001- \\
2000000\end{array}$ & $\begin{array}{l}2000001- \\
2500000\end{array}$ & $\begin{array}{l}2500001- \\
3000000\end{array}$ & $\begin{array}{l}\text { More than } \\
3000000\end{array}$ & \\
\hline Count & 7.0 & 32.0 & 39.0 & 13.0 & 8.0 & 6.0 & 9.0 & 114.0 \\
\hline Total & $1.8 \%$ & $8.0 \%$ & $9.8 \%$ & $3.3 \%$ & $2.0 \%$ & $1.5 \%$ & $2.3 \%$ & $28.5 \%$ \\
\hline Count & 5.0 & 41.0 & 35.0 & 11.0 & 0.0 & 0.0 & 7.0 & 99.0 \\
\hline Total & $1.3 \%$ & $10.3 \%$ & $8.8 \%$ & $2.8 \%$ & $0.0 \%$ & $0.0 \%$ & $1.8 \%$ & $24.8 \%$ \\
\hline Count & 0.0 & 10.0 & 34.0 & 9.0 & 0.0 & 1.0 & 4.0 & 58.0 \\
\hline Total & $0.0 \%$ & $2.5 \%$ & $8.5 \%$ & $2.3 \%$ & $0.0 \%$ & $0.3 \%$ & $1.0 \%$ & $14.5 \%$ \\
\hline Count & 2.0 & 5.0 & 2.0 & 46.0 & 4.0 & 4.0 & 5.0 & 68.0 \\
\hline Total & $0.5 \%$ & $1.3 \%$ & $0.5 \%$ & $11.5 \%$ & $1.0 \%$ & $1.0 \%$ & $1.3 \%$ & $17.0 \%$ \\
\hline Count & 5.0 & 0.0 & 2.0 & 4.0 & 0.0 & 23.0 & 2.0 & 36.0 \\
\hline Total & $1.3 \%$ & $0.0 \%$ & $0.5 \%$ & $1.0 \%$ & $0.0 \%$ & $5.8 \%$ & $0.5 \%$ & $9.0 \%$ \\
\hline Count & 0.0 & 2.0 & 0.0 & 0.0 & 0.0 & 0.0 & 6.0 & 8.0 \\
\hline Total & $0.0 \%$ & $0.5 \%$ & $0.0 \%$ & $0.0 \%$ & $0.0 \%$ & $0.0 \%$ & $1.5 \%$ & $2.0 \%$ \\
\hline Count & 1.0 & 6.0 & 0.0 & 1.0 & 2.0 & 0.0 & 7.0 & 17.0 \\
\hline Total & $0.3 \%$ & $1.5 \%$ & $0.0 \%$ & $0.3 \%$ & $0.5 \%$ & $0.0 \%$ & $1.8 \%$ & $4.3 \%$ \\
\hline Count & 20.0 & 96.0 & 112.0 & 84.0 & 14.0 & 34.0 & 40.0 & 400.0 \\
\hline Total & $5.0 \%$ & $24.0 \%$ & $28.0 \%$ & $21.0 \%$ & $3.5 \%$ & $8.5 \%$ & $10.0 \%$ & $100.0 \%$ \\
\hline
\end{tabular}

Out of 58 migrants in the earning group of 1000001-1500000Rls. per month before migration, $58.6 \%$ were in the same group after migration and $17.2 \%$ of migrants had moved to a lower group than before migration whereas $24.1 \%$ had shifted to higher earning groups compare to their earlier status.

In the fourth earning group (1500001-200000Rls) most of migrants $(67.6 \%)$ had no shift and were in the same earning level at the time of survey and the earning of $19.2 \%$ had increased and reached to a higher earning level group. Only $13.3 \%$ of migrants in this group were pushed to a lower earning level group.

Majority (63.9\%) of the migrants in the earning group of 2000001-2500000Rls. moved to the next earning group after migration but about $30.6 \%$ of migrants in this group had decrease in their earning after migration to the city.

Out of 8 migrants in sixth earning group of 2500001-3000000Rls. per month before migration 6 migrants (75\%) moved to a higher level of earning and 2 migrants moved to a lower earning level.

Out of 17 migrants in the earning group of above $3000000 R 1 s$. per month before migration, $41.2 \%$ were in the same group after migration to the city and rest of them had been pushed to a lower earning group after migration to the city.

Earning members of the respondent households: The number of earning members per family shows the labour supply and it determines the total family income. Understanding of the number of earning member per households will help to further analyses the income of the households and the dependent population ratio in the migrant households.
Table 3: Earning members of the migrant households

\begin{tabular}{lllll}
\hline & \multicolumn{2}{l}{ Number of earning members per family } & \\
& 1 & 2 & 3 & Total \\
\hline count & 351 & 37 & 12 & 400 \\
Percent & $87.8 \%$ & $9.3 \%$ & $3.0 \%$ & $100 \%$ \\
\hline
\end{tabular}

Table 3 reveals that the maximum number of earning members per household is three and the majority of the household has a single earning member. The average earning member per household of the respondents is 1.15 persons, which are lower of similar percentage for non-migrant. This is because of existing more opportunity for natives especially in Iran which relationship and information play a significant role in getting any job, and natives have more information about labour market.

Determinants of earning: Analyzing the earning structure of the migrants and the hypothesized determinants of earning like age, education, sector of employment will help us to know the influence of determinants on migrants' earnings, and also in order to understand the effect of the urban experience and urban contact in finding job before migration on migrants' earnings, related variables added to equation.

The dependent variable used is the natural logarithm of cash earnings (LnE). The independent variables that have been hypothesized as determinants of earnings and their definition as follows:

Variables Definition

Age Actual age at the time of survey

AgeSQ Age squared

DumIlli Dummy variable equal to 1 , if has no education, 0 otherwise 
DumPrim Dummy variable equal to 1 , if has primary education, 0 otherwise

DumSec Dummy variable equal to 1 , if has secondary education, 0 otherwise

DumDeg Dummy variable equal to 1 , if has degree education, 0 otherwise

DumOth Dummy variable equal to 1, if household has income from agriculture and property, 0 otherwise

DumFor Dummy variable 1 if occupied in formal sector 0 otherwise

DumSelf Dummy variable equal to 1 if selfemployed 0 otherwise

URBEX Urban experience as a resident

URBEXSQ Urban experience square

DumSUB Dummy variable equal to 1 if sources to set job is urban based contact (Friends and relatives)

The linear regression model is considered an appropriate tool to analyze the significance of explanatory variables on the migrant's earning. In the primary analysis 13 cases with standard residual (have a mean of 0 and standard deviation of (1) more than \pm 3 were excluded. Findings are based on the remaining 387 cases.

In general all exogenous variables in the model explain more than $60 \%$ of variation of dependent variable and Variance Inflation Factor (VIF) for them is less than 5 which indicate that multicollinearity is not serious. The residual plot looks good and there is no definite pattern, and all residuals are between \pm 3 and value of durbin-watson test is about 2 (Table 4), so the model is free from serial correlation. The calculated Fvalue is statistically significant at $1 \%$ level (Table 5). Then in overall model fit is good and based on ANOVA table the model is significant.
Table 6 show the regression analysis of earnings of the migrants alone.

Age and age square (Age, AgeSQ) have expected positive and negative signs respectively, and calculated coefficient is statistically significant at $1 \%$ level. The additional years of age increased the earnings by $10.2 \%$. The negative influence of the age square shows that after a certain age the additional years of age reduces the earnings, but it is very negligible percentage (1\%).

Urban experience variables (URBEX, URBEXSQ) have negative and positive sign, respectively, and the calculated coefficients are not statistically significant.

Years of services (YERSE) in the present job has positively influence on earnings and the calculated coefficient is statistically significant at $5 \%$ level. This shows that an additional year of service in the present job increases the earnings by $0.8 \%$.

Illiteracy has a negative and significant effect at $1 \%$ level on earnings and determines the earnings by $36.5 \%$. Secondary and degree education influence positively on earning but secondary education's effect is not significant whereas degree education's effect is significant at $5 \%$ level and determines the earnings by $20.1 \%$. Degree educated migrant respondents earn

Table 4: Model Summary

\begin{tabular}{llllll}
\hline Model & $\mathrm{R}$ & $\mathrm{R}^{2}$ & $\begin{array}{l}\text { Adjusted } \\
\mathrm{R}^{2}\end{array}$ & $\begin{array}{l}\text { Std. error of } \\
\text { the estimate }\end{array}$ & $\begin{array}{l}\text { Durbin- } \\
\text { watson }\end{array}$ \\
\hline 1 & 0.832 & 0.692 & 0.683 & 0.30202 & 1.920 \\
\hline Dependent variable: $\mathrm{LnE}$ & & &
\end{tabular}

Table 5: Anova

\begin{tabular}{lllllll}
\hline Model & & $\begin{array}{l}\text { Sum of } \\
\text { squares }\end{array}$ & df & $\begin{array}{l}\text { Mean } \\
\text { squares }\end{array}$ & F & Sig. \\
\hline 1 & Regression & 76.892 & 11 & 6.990 & 76.634 & 0.000 \\
& Residual & 34.206 & 375 & 0.091 & & \\
& Total & 111.098 & 386 & & & \\
\hline
\end{tabular}

Dependent variable: LnE

Table 6: Coefficient of the Model

\begin{tabular}{|c|c|c|c|c|c|}
\hline & \multicolumn{2}{|c|}{ Unstandardized coefficients } & \multirow{2}{*}{$\begin{array}{l}\text { Standardized } \\
\text { coefficients } \\
\text { Beta }\end{array}$} & \multirow[b]{2}{*}{$\mathrm{t}$} & \multirow[b]{2}{*}{ Sig. } \\
\hline & $\mathrm{B}$ & Std. error & & & \\
\hline$\overline{\text { (Constant) }}$ & 15.006 & 0.286 & & 52.536 & 0.000 \\
\hline Age & 0.063 & 0.009 & 1.313 & 7.097 & 0.000 \\
\hline AgeSQ & -0.001 & 0.000 & -1.251 & -7.016 & 0.000 \\
\hline Urban experience & -0.050 & 0.073 & -0.198 & -0.678 & 0.498 \\
\hline URBEXSQ & 0.008 & 0.005 & 0.478 & 1.614 & 0.107 \\
\hline Dummy V.1 if has no education, 0 otherwise & -0.365 & 0.040 & -0.286 & -9.054 & 0.000 \\
\hline Dummy V. 1 if has secondary education, 0 otherwise & 0.022 & 0.024 & 0.028 & 0.929 & 0.354 \\
\hline Dummy 1 if has degree education, 0 otherwise & 0.201 & 0.064 & 0.100 & 3.139 & 0.002 \\
\hline Actual years of service in present job & 0.008 & 0.004 & 0.118 & 2.095 & 0.037 \\
\hline Dummy v. 1 if sources to get job is urban based contact & 0.068 & 0.039 & 0.055 & 1.743 & 0.082 \\
\hline Dummy v. 1 if occupied in formal sector 0 otherwise & 0.267 & 0.042 & 0.206 & 6.301 & 0.000 \\
\hline Dummy v. 1 if self-employed 0 otherwise & 0.324 & 0.037 & 0.282 & 8.830 & 0.000 \\
\hline
\end{tabular}

Dependent variable: LnE 
$37.74 \%$ more than secondary educated migrant respondents and those of migrants that have no education are earning $27 \%$ less than secondary educated migrants.

Most of study shows that urban contacts before migration via friends and relatives in the city have played a major role in getting jobs for migrants, in other word migration network can reduce information cost and providing direct job research assistance in order to find better job and consequently better earning ${ }^{[24]}$. Empirical evidence from around the world has shown that migrant networks have significant impact on migration and earning of migrants ${ }^{[25]}$. Results of our analysis confirm that such these contacts in order to find job in city influence on earnings that come from finding better job position. The dummy variable DumSUBC (if sources to get job is urban based contacts) has expected positive sign and is significant at $10 \%$ level. This variable determines earnings by $7.03 \%$.

The sectors of employment variables (DumFor and DumSelf) have positive and significant effect at $1 \%$ level on earnings. The employment in the formal sector determines the earnings by $30.6 \%$ and self-employment determines the earnings by $38.26 \%$. The self-employed migrants earn $12.85 \%$ higher than the migrants employed in the formal sector.

\section{CONCLUSION}

The study has explored the impact of migration on migrant's earning, using primary data from Iran and the analysis has also highlighted factors influencing migrant's earning.

The finding underscores the importance of anticipated earning gains for different earning level groups. The average earning of migrants has increased by $65.11 \%$ after migration, which mostly has earned by the principle migrant of household. Age, higher education and work experience have significant effect on earning as well as employment sectors. We also find support for the positive influence of network migration on migrant's earning in Iran.

In conclusion inequality of earning between rural and urban area has accelerated migration, and since this kind of migration increase poverty by itself in rural area then at the same time, migration stands as a cause in producing of inequality. So the gap between rural and urban will be increased rapidly. Consequently, it is necessary for government to tackle the existing gap between these two areas.

\section{REFERENCES}

1. Ravenstein, E., 1889. The laws of migration. J. Roy. Stat. Soc., 52: 241-305. http:/www.jstor. org/journals/09528385.html? cookieSet $=1$.

2. Sjaastad, L.A., 1962. The costs and returns of human migration. J. Polit. Econ., 70: 80-93. http://www.journals.uchicago.edu/toc/jpe/current.

3. Todaro, M., 1969. A model of labor migration and urban unemployment in less developed countries. Am. Econ. Rev., 59: 138-148. http://www.aeaweb.org/aer/.

4. Lee, E.S., 1966. A theory of migration. Demogr. India, 3: 47-57.

5. Mimura, Y. and T. Mauldin, 2005.American young adults rural-to-urban migration and timing of exits from poverty spells. J. Fam. Econ. Issues, 26: 55-76. http://www.springerlink.com/content/ 104904/.(access on 25.6.2008).

6. Kerichel, T. and P. Levine, 1999. The welfare economics of rural-to-urban migration:The harristodaro model revisited. J. Reg. Sci., 39: 429-447. http://www.blackwellpublishing.com/journal.asp?r ef $=0022-4146 \&$ site.

7. Mitra, A. and Y. Tsujita, 2006. Migration and Wellbeing at the Lower Echelons of the Economy: A Study Of Delhi Slums. IDE Discussion Papers, No. 051, IDE-JTERO. Chiba, Japan,

8. Boakye-Yiadom, L. and A. McKay, 2007. Migration between Ghana's Rural and Urban Areas: The Impact on Migrants Welfare. http://www.pegnet.ifw-kiel.de/papers/conference2007

9. Santhapparaj, A.S., 1996. Job search and earning of the migrants: A study of the madurai metropolis. Indian J. Lab. Econ., 39: 269-286. http:/www. isleijle. org/NormalView.asp?m_id=141.

10. Majumdar, P.S., 1978. Rural Migrants in an Urban Setting. Hindustan Publishing Corporation, Delhi.

11. Kuznets, S., 1966. Modern Economic Growth: Rate, Structure and Spread. First ed. Yale University Press, New Haven.

12. Harris, J.R. and M. Todaro, 1970. Migration, unemployment and development: A two-sector analysis. Am. Econ. Rev., 60: 126-142. http://www.aeaweb.org/aer/.

13. Cross, C. (2001). Why Does South Africa Need a Spatial Policy? Population Migration, Infrastructure and Development. J. Contemp. Afr. Stud., 19(1): 111-127, DOI: $10.1080 / 02589000123491$ 
14. Temple, J. R. W. (2005). Growth and Wage Inequality in a Dual Economy. Bull. Econ. Res., 57(2): $\quad$ 145-169. DOI: $\quad 10.1111 / \mathrm{j} .0307-$ 3378.2005.00218.x

15. Safa, H.I. and B.M.D. Toit, 1975. Migration and Development. 2nd ed., Mouton Publishers, Chicago.

16. Hugo, G.J., 1991. Rural-urban migration, economic development and social change: Some important issues. In: Workshop on the Urbanization and Urban Poor. Bangladesh Institute of Development Studies,July 27-29, Dhaka. http://www.bidsbd.org/.

17. Wintle, M., 1992. Push-factors in emigration: The case of province of zeeland in the nineteenth century. Popul. Stud., 46: 523-527. http://www.informaworld.com/smpp/title $\sim$ content= $\mathrm{t} 713689546 \sim \mathrm{db}=$ all.

18. Selvaraj, K.G. and P.S.S. Rao, 1993. Household migration-urbanization and consequences. Demogr. India, 22: 203-210.

19. Mohtadi, H., 1990. Rural inequality and rural-push versus urban-pull migration: The case of Iran, 1956-1976. World Dev., 18(6): 837-844, DOI:10.1016/0305-750X(90)90006-J

20. National Portal of Statistic. (2008,July 2). Average Annual Income of an urban/Rural Household by sources of Income, Avalable: http://www.sci.org.ir/portal/faces/public/sci_en/sci en.selecteddata/sci_en.yearbookdata[2008,July 2].
21. Sheykhi, M. T., 2007. Youth Housing Conditions in Tehran: Profiles and Challenges. J. Soc. Sci., 15(2): 153-160. (ISSN: 0971-8923).

22. Ali, M. and H. Ghaffari, 1998. Economic determinants of rural labour migration. Indian J. Lab. Econ., 41: 794-796. ttp://www.isleijle. org/NormalView.asp?m_id=141.

23. Kannappan, S., 1985.Urban employment and the labor market in developing nations. Econ. Dev. Cult. Change, 33: 699-730. http://www.journals. uchicago.edu/loi/edcc.

24. Massey, D.S. et al., 1993.Theories of international migration: A review and appraisial. Popul. Dev. Rev., 19: 431-466. http://www. blackwellpublishing.com/journal.asp?ref=00987921.

25. Zhao, Y., 2003. The role of migrant networks in labor migration: The case of China. Contemp. Econ. Pol., 21: 500-511. http://www. blackwellpublishing.com/journal.asp?ref=10743529 . 